Hudáková T.

\title{
Prevention of ventilator-associated pneumonia in intensive departments from the nursing perspective
}

\author{
St. Elizabeth University of Health and Social Sciences, Bratislava, Slovakia
}

s.tana@centrum.sk

\section{Introduction}

The knowledge and practices of contemporary modern medicine based on evidence create an environment in which healthcare professionals can often save seemingly lost human lives. The current standard of hospital wards is improved by not only qualified medical professionals, but also by modern medical equipment which facilitates the work of healthcare personnel and helps to save human lives. However, modern advances in healthcare also bring new risks for patients in the form of nosocomial infections which occur in the healthcare facilities and are related to modern medical equipment involved in saving human lives. Nosocomial infections are considered to be a major issue in the healthcare facilities. They contribute to the morbidity and mortality increase in the inpatients, prolong the stay of inpatients in sickbed and increase the treatment costs. In up to $10 \%$ of all inpatients nosocomial infection occur. It has been shown that programs designed to control hospital infections can reduce their incidence by as many as $33 \%$. Studies which deal with nosocomial pneumonias are mostly done in the USA and European countries, the so-called high-income countries, studies from other parts of the world, the so-called low-income countries are rare (Abdel-Fattah, 2008).

The highest incidence of nosocomial infections worldwide is documented in the anaesthesiology and intensive care units, where due to the healthcare provided and the overall life-threatening condition of patients, the largest number of risk factors are present. Each hospital and ward have its own pathogens and resistant strains, which are also a big problem. Lower respiratory tract infections - ventilator-associated pneumonia are considered to be the lower nosocomial infections with the highest incidence. Nosocomial infections prolong the time of hospitalization, increase the treatment costs and have a number of negative health and social consequences for the patient. Prevention of nosocomial infections is one of the very current problems that can significantly help to improve the health care. It is a specific process that requires nurses to have knowledge of the methods and possibilities of nosocomial infections prevention, to acquire certain habits aimed at prevention. The nurse's responsibility and interest in taking preventive measures should be part of the nursing care. Ventilator-associated pneumonia is an important determinant of the length of the hospitalization in the intensive care unit, total length of hospitalization and healthcare costs.
Preventive measures will help to improve the final health condition of the patients. Preventive measures that are part of the nursing care should be initiated mainly by the nurse to ensure the continuity of the preventive measures. In the prevention of ventilator-associated pneumonia, as reported by Firment et al. (2014 p. 299), "the most important, but also the most vulnerable point of prevention is the acceptance of the established procedures by the nursing staff."

Ventilator-associated pneumonia in intensive care units. Artificial respiration (AR) is a set of measures to support or replace the activity of some failing components of the respiratory system - the lungs, chest wall, respiratory muscles. Its main function is to support the exchange of gases in the lungs to affect the size of the lung volume. The decision to indicate $\mathrm{AR}$ is made on the basis of the patient's clinical condition. These include diseases of various etiologies, the consequences of injuries, which are accompanied by a failure of ventilation or respiration. These are most often diseases of the nervous and musculoskeletal system, but also pneumological and cardiac diseases. However, artificial respiration is associated with a number of complications, one of which is the possibility of ventilator-associated pneumonia (Bartůněk, et al., 2016).

Ventilator-associated pneumonia (VAP) is associated with high mortality and morbidity, prolonged ventilator connection, long-term intensive care, and high healthcare costs. Gross mortality from ventilator-associated pneumonia is reported in the range of $20-71 \%$, but many critically ill patients die of their underlying disease rather than ventilator-associated pneumonia. Such mortality is mainly related to the severity of the disease at the time when the patient is diagnosis with ventilator-associated pneumonia, the underlying disease and comorbidity. Old age, inappropriately chosen ATB therapy after making the diagnosis and an infectious agent that causes pneumonia all play an important role. Increasing mortality rate is associated with bacteraemia, especially with pathogens such as Pseudomonas aeruginosa and Acinetobacter spp. Ventilatorassociated pneumonia caused by multidrug-resistant pathogens results in gross and attributable mortality increase (Klimešová, Klimeš, 2011).

According to Bartůněk et al. (2016) the measures of VAP prevention include a general hygiene regime that focuses on thorough hygienic disinfection of hands with alcohol before and after working with the patient, proper organization of work with appropriate workload and strict approach to ATB 
administration in preventive and indicated cases, ensuring elevated torso position in patients, which reduces the risk of regurgitation and aspiration of gastric and pharyngeal contents, patient positioning prevents and treats small atelectasis, suctioning of subglottic and pharyngeal secretion above the endotracheal tube balloon (ETK), closed respiratory system with closed suctioning system and minimal disconnection of the breathing circuit, timely removal of the nasogastric tube, stimulation of the gastrointestinal tract, selective decontamination of the intestine in at-risk patients. Patients on AR need a specific approach from the nursing staff and in collaboration with a multidisciplinary team. AR is one of the basic services in intensive care, and therefore the personnel and material equipment of the unit are very important (Klimešová, Klimeš, 2011).

In all ventilated patients, the incidence of VAP is about $10 \%$, these pneumonias increase mortality from the original acute disease 2-4 times and the mortality from VAP itself is about $13 \%$. The extent of the VAP hazard is given by the underlying diagnosis, the overall health condition of the patient, the cause of the inflammation and the patient age (Zadák, et al, 2017).

Pneumonia is most often caused by the secretion of mucus, which accumulates in the subepiglotteum, or this secretion accumulates above the sealing cuff of the tube and then flows into the trachea. Microbes can also enter the sterile parts of the airways during intubation, creating a biofilm at ETK. We divide pathogenic microorganisms into groups I and II. Group I pathogens are commonly found in the airways and include Staphylococcus aureus, Haemophilus influenzae, Streptococcus pneumoniae, Moraxella catarhallis and others. These pathogens cause early VAP, which occurs within 4 days of the onset of AR and represent the dominant part of the VAP causative agents. Group II pathogens are represented by microorganisms that were not present in the patient at the time of intubation and initiation of AR. These are pathogens include Klebsiella pneumoniae, Pseudomonas aeruginosa, Escherichia coli, MRSA-methicillin resistant Staphylococcus aureus, Enterobacter cloacae, Acinetobacter, Serratia marcescens and others. We meet with these causative agents in late VAP, i.e. in VAP from the 5th day of AR initiation (Dostál, et al., 2014).

Several factors contribute to the onset of VAP and the influence of the severity of its course. The most significant risk factor is considered to be AR that is longer than 24 hours. Other factors include age, severity of the underlying disease, immunosuppression, smoking, male gender, cardiopulmonary disease, obesity, antibiotic treatment, thoracoabdominal surgery, presence of enteral probe, seasonal effects (autumn, winter), inability to cooperate with the patient and others (Šrámová, et al., 2013).

Several scoring systems have been developed to determine the occurrence probability. One of them is the CPIS system - Clinical pulmonary infection score introduced by Pugin and it has various modifications (Dostál, et al., 2014).

Interventions that are implemented in the VAP prevention have been the subject of various clinical studies for a long time. One series of identified factors causing VAP is directly related to the way nursing and health care are provided.
Created packages of measures - VAP boundles, that are used to prevent VAP represent methods by which the incidence of VAP can be effectively reduced when providing nursing care to the patient on AR. The packages created to eliminate VAP contain several components that are considered essential when it comes to the prevention of VAP occurrence and spread (CPSI ICSP, 2013).

Oral cavity toilet of patients on AR. Oral cavity (OC) hygiene (is a set of activities which aims to prevent disease changes in the teeth and inflammation of the oral cavity (OC). Regular oral hygiene prevents it from drying out, avoids inflammation of the mucous membranes, prevents bad breath and makes the communication more pleasant. Proper care of the OC plays an important role in the VAP prevention; however, many nurses underestimate this fact and do not pay enough attention to OC care (Alhazzani, et al., 2013).

The AACN (American Association of Critical-Care Nurses) guidelines recommend brushing the teeth twice a day and wiping the $\mathrm{OC}$ using foam brushes every two to four hours. It is important to keep the mucous membranes moist, regular humidification of the $\mathrm{OC}$ is appropriate, e.g. by physiological saline. Using a toothbrush is a simple and effective method for mechanical removal of dental plaque. Nevertheless, in the case of many inpatients, only foam brushes are used for oral cavity hygiene, which are, however, insufficient when it comes to removing the dental plaque (Gmür, 2013).

For patients with UVP, it is necessary for the nurse to perform the oral cavity hygiene. If the hygiene is neglected, it results in the over-reproduction of bacteria and subsequent bacterial colonization of the oropharynx and the development of VAP. For patients with AR, it is recommended to do the oral cavity hygiene at least every three hours and it should include mechanical removal of dental plaque, removal of plaque and secretions from the OC, suctioning from the nasopharyngeal area of the patient. With regard to the recommended procedures for the prevention of VAP, it is appropriate to use disposable devices (toothbrushes, brushes, suctioning hoses) with the simultaneous use of preparations that contain an antiseptic component - chlorhexidine. It is a broad-spectrum antibacterial preparation that acts against gram-positive and at the same time against multiresistant microorganisms. To optimize the procedure and increase the effect of the oral cavity hygiene and to reduce the development of VAP, it is recommended to keep the oral care protocols (Streitová, et al., 2015).

Skinsept Mucosa, Chlorhexidine and Paradontax, which are the most frequently used ones, contain a certain amount of chlorhexidine, which is recommended for the care of the oral cavity in connection with the VAP prevention. It should be noted that preparations that contain chlorhexidine should be used at certain intervals; with the active ingredient being released gradually. Meanwhile, the OC should be moistened every 2-4 hours using a solution that does not interact with chlorhexidine. Herbal decoctions are recommended, e.g. from Agrimonia eupatoria, sage, chamomile or water. It should be stressed that chlorhexidine cannot replace mechanical cleaning of OC (Perlík, 2008). 
Airways toilet of patients on AR. The toilet of the lower respiratory tract (LRT) is one of the basic procedures for nurses who work in the intensive care units. In the case of intubated patients on AR, the care is secured by tracheal suctioning, at which the ETK must be fixed sufficiently to prevent it from dislocating and pulling out. Suctioning from the LRT is determined on the basis of the patient's needs and it is always required before and after the administration of nebulization. It can be traumatic, so it is always necessary to perform it as gently as possible, it is done using a short-term intermittent under-pressure, which is in the range of the following values $(80-120 \mathrm{mmHg}, 10.7-16 \mathrm{kPa}, 107-160 \mathrm{mBar})$. The correct suctioning technique is done in such a way that a sterile suctioning catheter is inserted to the site of firm resistance - the carina area, then it is pulled out a little by $1 \mathrm{~cm}$ and at a constant intermittent suctioning, control of nature and sputum coloration it is pulled out. If repeated suctioning is required, it must be repeated after 3-4 breath cycles. During the suctioning, it is necessary to monitor the vital functions; in the event of a vagal reflex manifested by bradyarrhythmia, the suctioning must be interrupted. In case of severe hyposaturation, the patient should be preoxygenated. When it comes to the implantation of tracheal suctioning technique from it is divided into suctioning by open and suctioning by closed system, while no significant differences were observed between these two techniques in the VAP development and incidence prevention (Dostál, et al., 2014).

Endotracheal cannula care. The care of the ETK in the patient on AR consists in maintaining the ETK patency, to prevent its twisting, clogging or biting by the patient who is in shallow sedation and who has poor tolerance of the ETK. The ETK fixation should be done using a fixation patch or bandage and should be replaced each time the ETK position is changed, contaminated or detached. It is necessary to pay attention to the manipulation with the ETK, especially during suctioning, positioning and rehabilitation, because its dislocation and artificial extubation may increase the risk of VAP development. To prevent the formation of the pressure ulcers in the oral cavity corner, it is recommended to change the position of the ETK at regular intervals. In practice, the most effective interval used is every 12 hours. The nurse must record the correctness of the ETK placement in the documentation together with the depth of the ETK insertion (Hees, 2015).

Suctioning from subglottic area. Contaminated OC secretion accumulates above the ETK cuff and migrates to the lungs even when the cuff is properly inflated. Permanent removal of this secretion by suctioning reduces the risk of aspiration as well as the risk of VAP development. The use of ETK with subglottic suctioning, reduces the risk of VAP development as well the time required for AR (Muscedere et al., 2011).

However, routine replacement of conventional ETK for ETK with suctioning from the subglottic area is not recommended as there is an increased risk of infection from higher levels of the airways during its replacement (Dostál, et al., 2014).
Suctioning from the subglottic area can be performed in two ways, either by intermittent or continuous suctioning. Intermittent suctioning is ideally performed every hour using a $10 \mathrm{ml}$ syringe, always before and after the OC toilet. Continuous suctioning is performed by connection to a permanent suctioning device with negative pressure (Streitová, Zoubková, 2015).

Humidification and heating of the inhaled mixture. Under physiological conditions, adequate humidification and heating of the inhaled air the is ensured by the upper respiratory tract. The patient on AR with ETK does not have this ability and it needs to be substituted (Kapounová, 2007).

The minimum temperature and humidity requirements for the inspiratory gas mixture in the carina area are $30^{\circ} \mathrm{C}$ and $70-100 \%$. Insufficient humidification and heating of the inhaled mixture results in atelectasis, secretions retention and increased sputum viscosity, slowing of mucociliary transport and subsequent lung damage accompanied by the risk of developing the infection (Bartůnek, et al., 2016).

Active and passive humidifiers are used to ensure the heating and humidification of the inspiratory gas mixture. Cascade humidifiers which contain sterile heated water, through which a mixture of gases flows, are used s for active heating, so the gases are heated and humidified. The heating intensity is regulated by a temperature sensor of the inspiratory mixture. Passive humidifiers, the so-called Heat and Moisture Exchangers (HME), are inserted between the patient's airways and the airway circuit (Dostál, et al., 2014).

The patient's position in the VAP prevention. An important part of the care for a patient with ETK is positioning and vibrating massage of the chest. The position of the unconscious patient should be changed at least once every three hours, unless the patient has a restraint or rest period. At each positioning of the patient, a vibrating chest massage, which helps to loosen the mucus plugs, is recommended (Drábková, Hájková, 2018).

Adjustment of the patient's position on AR is one of the simplest and most effective nursing interventions which eliminate the VAP development. The basic position for the ventilated patients in the VAP prevention is the semirecumbent or Fowler position, which is characterized by semi-sitting and lifting of the upper body part by $30-45^{\circ}$. The patient's torso is in an elevated position, the correct bend is at the level of the hips, not at the waist. The bend in the area of the waist causes a restriction of the movement of the diaphragm and its weakening. It is recommended to place a smaller cushion under the patient's head to compensate for cervical lordosis and to prevent excessive forward bending or tilting of the head. An integral part of the positioning regime is the positioning of the patient on the hips, which has a positive effect on facilitating the release of mucus and its suctioning. From the point of view of pathophysiology, there is increased perfusion on the laid side of the lungs and better aeration on the upper side of the lungs and at the same time, the influence of gravity supports the drainage of mucus and its easier suctioning. The basic rule in the prevention of VAP is the rule that the increased position of upper half of the body of the patient on AR should be 
performed in all situations of nursing care, including positioning on the hips (Streitová, Zoubková, 2015).

Enteral nutrition and its relation to VAP. Malnutrition of the patient is associated with an increased risk of VAP development. Early initiation of enteral nutrition in critically ill patients (if not contraindicated) is beneficial because it improves the integrity of the intestinal wall. The method of enteral nutrition administration using a probe placed in the jejunum may reduce the risk of VAP development when compared to gastric probes. However, when administering enteral nutrition, it is necessary to monitor the gastric residue, in order to early detect the stagnation of gastric contents to prevent possible regurgitation and aspiration. Progressive continuous administration of enteral nutrition can increase gastric volume, which in combination with an unfavourable position, reduced gastrointestinal tract motility and the presence of a nutritional probe (potential contaminant) can lead to gastric leakage into the lower respiratory tract and result in late VAP form. To reduce the risk of such complication, intermittent administration of enteral nutrition is preferred with a night fasting pause of 4-6 hours (Sas, 2010).

Ventilation circuit care. Ventilation circuit care is an integral part of a nurse's work tasks in the intensive care unit in when providing nursing care to a ventilated patient. Ventilation circuits have a standard inspiratory and expiratory arm, which is connected by the so-called Y connector, which enables one to connect individual components with ETK (Dostál, et al., 2014).

In the VAP prevention and the prevention of spread of nosocomial infections, it is important that the ventilation circuits are assembled under strict sterile and aseptic conditions. Special attention must be paid to the arising condensate on the circuit walls. It must be removed regularly to prevent condensed fluid from entering the lower airways and to minimize manipulation, i.e. disconnection of the ventilation circuit which represents an increased risk of contamination. If the principles of asepsis are followed, the frequency of the ventilation circuit replacement is indicated every 7 days. The latest findings within the VAP prevention recommend to replace ventilation circuits only in the event of damage, contamination and between individual patients. In practice, this means that one ventilation circuit is sufficient for the entire ventilation support period. Couplings, disposable suctioning systems and nebulization systems are recommended to be preventively changed while maintaining their functionality after at least 48 hours. The HME filters should be changed once every 24 hours and always when they are not functional (Barasch, 2015).

Current recommendations in VAP prevention. The findings of a meta-analysis that was published in the British Journal of Anaesthesia under the title Closed tracheal suctioning system for prevention of ventilator-associated pneumonia suggest that the use of a closed suctioning system cannot be used in practice as a protective factor in the VAP prevention because its benefit over open system suctioning has not been confirmed. By contrast, it has been shown that with increasing AR duration and concomitant use of a closed system, the airways of patients were colonized by pathogens up to $95 \%$ when it was repeatedly used. On the contrary, the benefit of a closed suctioning system is clear in patients on AR with high ventilation support, when the ventilation parameters do not decrease and it also protects the nursing staff due to the absence of its disconnection as there are no leaks of pathogens, aerosols and gases (Intersurgical, 2017).

The study entitled Oral Chlorhexidine Use to Prevent of Ventilator-Associated Pneumonia in Adults discusses the beneficial effect of the use of chlorhexidine gluconate in the oral cavity hygienic care of patients on $\mathrm{AR}$, the results of which show a significant reduction in the incidence of VAP at its use (Szuckerman, 2017).

Labeau et al. (2011) carried out a research on the assessment of the effect of oral cavity care using chlorhexidine in the VAP prevention. The research sample consisted of 2341 patients and the results showed a strong evidence for the benefit of the oral antiseptic chlorhexidine in the oral cavity care in the VAP prevention compared to the oral cavity care without oral decontamination. A particular effectiveness was observed at a concentration of $2 \%$ chlorhexidine especially in cardiac surgery patients. However, the recommended administration of $0,12 \%$ chlorhexidine had no significant effect in reducing the risk of pneumonia.

In connection with the benefit of using subglottic suctioning, 13 randomized clinical trials were identified that met the inclusion criteria with the total number of 2442 patients. Of the 13 studies, 12 studies reported a reduced speed of the development of the ventilator-associated pneumonia. The use of ETK with the possibility of drainage from the subglottic area was associated with a reduced length of stay in the intensive care unit and a prolonged time of VAP development. The conclusion of these studies is that in patients who are at risk of developing VAP, the use of ETK with the possibility of subglottic suctioning is effective in the VAP prevention and shortens the length of AR need and the length of stay in intensive care unit (Muscedere, et al., 2011).

It is also important to maintain and monitor the pressure in the obturation cuff. In Birmingham, New Cross Hospital, a successful study was done in 2015. It examined the use of the PneuX system, which has been shown to reduce the incidence of VAP in the patients on AR by up to $50 \%$. This system minimizes the risk of pulmonary aspiration and microaspiration in ventilated patients. It consists of an endotracheal tube, a tracheal seal monitor and an extension tube. The low-pressure cuff and tracheal seal monitor are made of soft material and act as an electronic automatic pressure regulator that controls and maintains the safe volume and pressure of the cuff volume during its use. At the same time, the system has significantly reduced hospital equipment costs in the use of antibiotics for the treatment of VAP in the intensive care units by as many as $50 \%$. The PneuX system is implemented in intensive care units at Massachusetts General Hospitals in Boston, USA and is encouraged for use in critically ill patients by lead intensive care consultants (NICE, 2015).

Akdogam et al. (2017) examined the influence of individual procedures and their combinations and identified hygienic hand disinfection, pressure control in the obturation cuff of ETK every four hours to keep the pressure between 
20-30 mm Hg, subglottic suctioning and care of OC using $2 \%$ chlorhexidine solution as the most effective procedures in VAP prevention. Elevated upper body position was not identified as the most important intervention.

The number of staff who cares for intensive patients is also related to the incidence of VAP in the intensive care units. This statement is supported by a prospective cohort study which deals with the nurse-patient ratio, the authors of which found that a higher number of nurses leads to a significant reduction in the risk of VAP development. Not only an adequate number of staff plays an important role, the level of knowledge of staff about VAP prevention strategies is equally important. The level of this knowledge in this study corresponded to the length of practice and education of nurses (Stozsek, et al., 2008). These statements are also supported by Dostál (2014, p. 340), who states that, "adequate staffing of the workplace leads to increased effectiveness of anti-infective and anti-epidemiological measures and reduces the duration of AR".

\section{Conclusions}

Ventilator-associated pneumonia is a serious complication that develops as a result of health and nursing care for ventilated patients hospitalized in the intensive care units. The issue of VAP prevention has long been the subject of intensive clinical research. The precondition for the introduction of preventive measures and their implementation in practice is expected to reduce the incidence of VAP (Novotný, 2015).

Success in VAP prevention means that healthcare professionals know what to do and how to do it, implement preventive strategies in care of patients in AR and in VAP prevention, there exists a standardization of the particular procedure in the particular wards and there are audits that evaluate individual procedures focused on care of patients in AR. The management personnel of the individual wards should purposefully support the staff in adhering to preventive strategies - only by doing so a common goal, namely the elimination of the occurrence of VAP in practice, can be achieved. Reducing the number of nosocomial infections is also a sign of the quality of healthcare services provided and for a given health facility it brings the reduction in the costs and reduction of the length of hospitalizations and success in the form of a cured patient, without unnecessary complications (Hudáková, Popovičová, 2020).

\section{References}

1. Abdel-Fattah, M.M. 2008. Nosocomial pneumonia: risk factors, rates and trends. In: Eastern Mediterranean Health Journal. 2008, ISSN: 1020-3397. vol.14, no.3. p. 338-348.

2. Alhazzani, W. et al. Toothbrushing for Critically Ill Mechanically Ventilated Patients. In: Critical Care Medicine. 2013, vol. 41, no. 2, p. 646-655.

3. Akdogan O, et al. 2017. Assessment of the effectiveness of a ventilator associated pneumonia prevention bundle that contains endotracheal tube with subglottic drainage and cuff pressure monitorization. In: The Brazilian Journal Of Infectious Diseases: An Official Publication Of The Brazilian Society Of Infectious Diseases. 2017, vol. 21, no. 3, p. $276-281$.

4. Barash, P. 2015. Klinická anesteziologie. Praha: Grada Publishing, 2015. 816 s. ISBN 978-80- 247-4053-9.

5. Bartůněk, P. et al. 2016. Vybrané kapitoly z intenzivní péče. Praha: Grada Publishing, 2016. 752 s. ISBN 978-80247-4343-1.

6. CPSI ICSP. Ventilator-associated pneumonia [online]. 2013. Dostupné z: http://www.patientsafetyinstitute.ca/en/ Topic/Pages/Ventilator-Associated-Pneumonia-(VAP).aspx

7. Dostál, P. 2014. Základy umělé plicní ventilace. Praha: Maxdorf Jessenius, 2014. 396 s. ISBN 978-80-7345-397-8.

8. Drábková, J., Hájková, S. 2018. Následná intenzivní péče. Praha: Mladá fronta a.s., 2018, 605s. ISBN 978-80-2044470-7.

9. Firment, J. a kol. 2014. Anestéziológia a intenzívna medicína. 3. vydanie. Košice: Univerzita P. J. Šafárika, 2014. 370 s. ISBN 978-80-8152-084-6.

10. Gmür, C. 2013 Survey on oral hygiene measures for intubated patients in Swiss intensive care units, Schweiz Monatsschr Zahnmed. Bern :Schweizerische Zahnärzte-Gesellschaft, 2013. ISSN: 0256-2855. r. 23, č. 3, s. $394-401$.

11. Hees, D. R. et al. 2015 Respiratory care: principles and practices. 3rd ed. Burlington: Jones and Bartlem Published, 2015, 1520 p. ISBN 978-1-284-0500-4.

12. Hudáková, T., Popovičová, M. 2020. Význam hygieny ústnej dutiny v prevencii ventilátorovej pneumónie. In: Sestra. 2020. ISSN: 1335.9444. r. 19, č. 1-2, s. 30-31.

13. Intersugical. Closed suction system [online]. 2017. Dostupné z: http://www. intersurgical.com/products/criticalcare/trachseal-closed-suction-systems-for-72-hours-use-with-saline-ampoules.

14. Kapounová, G. 2007. Ošetřovatelství v intenzivní péči. 1. vydání. Praha: Grada Publishing, 2007.368 s. ISBN 978-80-247-1830-9.

15. Klimešová, L., Klimeš, J. 2011. Umělá plicní ventilace. 1. vydání. Brno: Národní centrum ošetřovatelství a nelékařských zdravotnických oborů, 2011. 110 s. ISBN 978-80-7013-538-9.

16. Labeau, S. O. et al. 2011. Prevention of ventilator-associated pneumonia with oral antiseptics: a systematic review and meta-analysis. In: Medical Sciences-Communicable Diseases. 2011. ISSN 1473-3099. r. 11, č. 11, s. 845-854. 
17. NICE, 2015. National institute for health and care excellence. [online]. PneuX for preventing ventilator-associated pneumonia in intensive care. [online]. Citované dňa: [2019-12-12]. Dostupné z: https://www.nice.org.uk/advice/mib45.

18. Muscedere. J., et al. 2011. Subglottic secretion drainage for the prevention of ventilator-associated pneumonia: a systematic review and meta-analysis. [online]. US National Librar of Medicine National Institutes of Health. Citované dňa [202012-02]. Dostupné z: https://www.ncbi.nlm.nih.gov/pubmed/21478738.

19. Novotný, P. 2015. Nozokomiální pneumonie ventilovaných nemocných. Rizikové faktory se zaměřením na vliv inhibitorů protonové pumpy, možnosti prevence. Hradec Králové, 2015. 36 s. Autoreferát disertační práce. Univerzita obrany Brno, Fakulta vojenského zdravotnictví.

20. Perlík, F. 2008. Základy klinické farmakologie. 1. vyd. Praha: Galén, 2008, 192 s. ISBN 9788072625284.

21. Sas, I. 2014. Možnosti prevence vzniku nozokomiálních infekcí. In: Pavel Ševčík a Martin Matějovič, ed. Intenzivní medicína. 3. přepracované a rozšířené vydání, Praha: Galén, 2014. 783-786 s. ISBN 978-80-7492-066-0.

22. Streitová, D., Zoubková, R. 2015. Septické stavy v intenzivní péči: ošetřovatelská péče. Praha: Grada Publishing, 2015. 170 s. ISBN 978-80-247-5215-0.

23. Stoszek, D. et al. 2008. Možnosti prevence nozokomiální pneumonie ventilovaných nemocných-aktuálni stav. In: Anesteziologie \& intenzivní medicína. 2003. ISSN 1214-2158. r. 3, č.3, s. 149-153.

24. Szuckerman, L., M. 2016. Oral Chlorhexidine Use to Prevent Ventilator-Associated Pneumonia in Adults. Dimensions of Critical Care Nursing [online]. 2016. Citované dňa [2020-11-02]. Dostupné z: https://www.ncbi.nlm.nih.gov/ pubmed/26627070153.

25. Šrámová, H. et al. 2013 Nozokomiální nákazy. Praha: Maxdorf s.r.o., 2013, 400 s. ISBN 978-80-7345-286-5.

26. Zadák Z., et al. 2017. Intenzivní medicína na principech vnitřního lékařství. Praha: Grada Publishing a.s., 2017, 448 s. ISBN: 978-80-271-02082-2.

Дата надходження рукопису до редакції: 26.05.2020 p.

Ventilator-associated pneumonia (VAP) pose a serious nosocomial infection for patient at intensive care unit. Important role in its prevention presents nurse, who provides care for ventilated patient. This report drives attention to preventive aspects of VAP from nurse's perspective, as is cleanse of oral cavity, airways maintenance, drainage of subglottic space, head position of patient on mechanical ventilator. We point to present recommendations and studies, which cover VAP prevention.

Key words: ventilator-associated pneumonia, nosocomial infection, prevention, nurse strategy.

Вентиляторно-асоційована пневмонія (ВАП), є серйозною внутрішньолікарняною інфекцією для пацієнта у відділенні інтенсивної терапії. Важливу роль у його профілактиці відіграє медсестра, яка забезпечує догляд за провітрюваним хворим. Цей звіт привертає увагу до профілактичних аспектів ВАП з точки зору медсестри, таких як очищення ротової порожнини, обслуговування дихальних шляхів, дренування підглоткового простору, положення голови пацієнта на механічному вентиляторі. Ми вказуємо на рекомендації та дослідження, які охоплюють профілактику ВАП.

Ключові слова: вентиляторно-асоційована пневмонія, внутрішньолікарняна інфекція, профілактика, стратегія медсестри.

Пневмония, связанная с искусственной вентиляцией легких (ВАП), представляет собой серьезную нозокомиальную инфекцию для пациента в отделении интенсивной терапии. Важную роль в ее профилактике играет медсестра, которая ухаживает за больным на ИВЛ. Этот отчет привлекает внимание к профилактическим аспектам ВАП с точки зрения медсестры, таким как очистка полости рта, поддержание дыхательных путей, дренирование подсвязочного пространства, положение головы пациента на аппарате искусственной вентиляции легких. Мы указываем, чтобы представить рекомендации и исследования, которые охватывают профилактику ВАП.

Ключевые слова: вентилятор-ассоциированная пневмония, внутрибольничная инфекция, профилактика, стратегия медсестры.

\section{Відомості про автора}

Hudáková Tatiana - PhDr., external graduant, St. Elizabeth University of Health and Social Sciences in Bratislava, Slovakia. s.tana@centrum.sk. 